\section{Using soil ancient DNA for the reconstruction of past environments: insights in the new applications of paleosols on well-dated tephras}

DOREEN YU-TUAN HUANG ${ }^{1}$, SAÚL RODRIGUEZ ${ }^{1}$, JONATAN KLAMINDER ${ }^{1}$, ANDY DUGMORE ${ }^{2}$ AND NICK CUTLER $^{3}$

${ }^{1}$ Department of Ecology and Environmental Science, Umeå University

${ }^{2}$ School of Geosciences, The University of Edinburgh

${ }^{3}$ The School of Geography, Politics and Sociology, Newcastle University

Presenting Author: doreen.huang@umu.se

Predicting the consequences of climate change and imminent environmental changes requires an understanding of past ecosystems and their responses to perturbations beyond the timescales of contemporary monitoring programs. Many proxies have been developed to reconstruct past environments, but most these only capture a small fraction of past biodiversity. Paleosols could have distinctive multi-layered structures formed by incremental accumulation over time. Their burial by younger soils or sediments such as tephra can preserve a 'signature' of past environment. Hence, paleosols may present a powerful archive of past terrestrial ecosystems and their changes through time.

We analyzed ancient DNA (aDNA) from a sequence of proglacial paleosols at a site in west Greenland and we were able to reconstruct variations the local plant community over the last 800 years. Strikingly, the vegetation changes seem to track disruptive human activities and changing land use, such as the human settlement and reintroduction of domestic animals. However, the buried soils and change of vegetation could not be well dated because of the absence of macrofossils for radiocarbon dating. Elsewhere, macroscopic tephra layers provide isochrons (time-parallel marker beds) to connect and synchronize sequences and to assign relative or calendrical ages using tephrochronology. Therefore, paleosols nested between tephra layers may provide ecosystem records of greater utility. We are currently analyzing aDNA in paleosols developed within sequences of precisely-dated tephras in Iceland to study changes of soil biodiversity. Notably, the Landnám tephra deposited in $877 \mathrm{AD}$ in southeast Iceland clearly separates the paleosols formed before and after Norse settlement, which first brought people and domestic animals to the island. Thus the paleosols underneath and above the Landnám tephra will provide a critical insight into both the potential of aDNA for environmental reconstruction and the changes of plant and soil macrofauna in response to human colonization, and subsequent impacts.

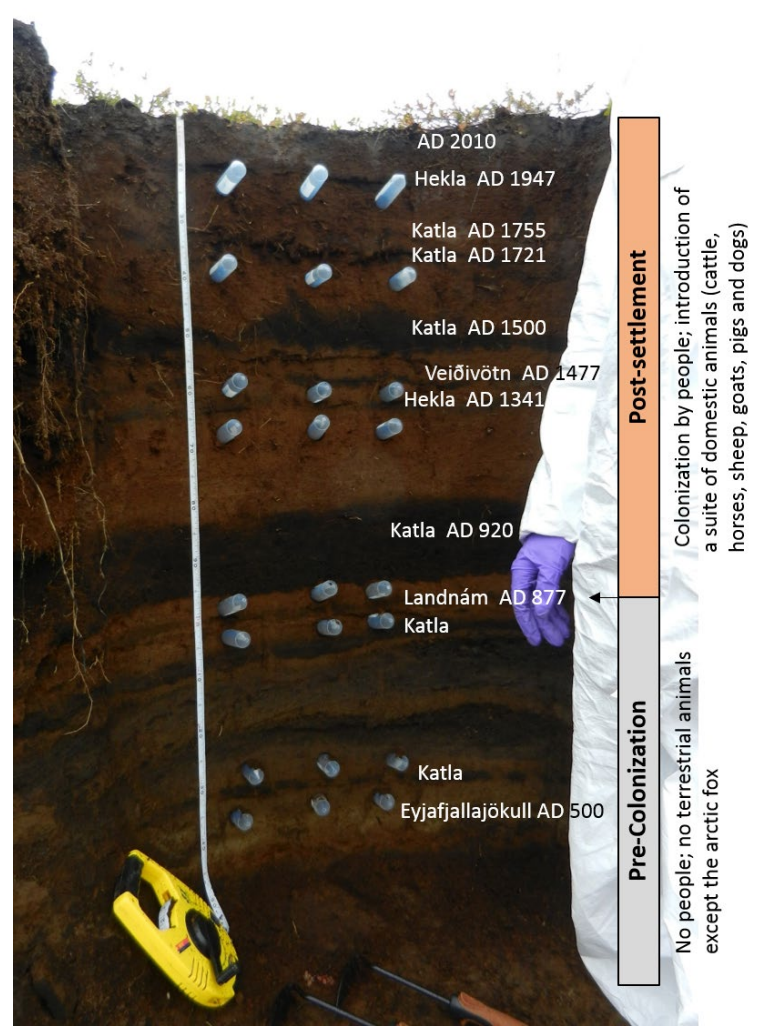

